\title{
Robeson v. State: Cross-Examination of Prearrest Silence
}

The Maryland Court of Special Appeals held that a criminal defendant who elects to testify may be cross-examined regarding his prearrest failure to volunteer his exculpatory version of events to the pohce after he learned that a warrant had been issued for his arrest. The court in effect permitted the prosecution to require charged criminal suspects to inform the police of their exculpatory stories before their arrest, on pam of impeachment should they take the stand at trial.

Part I of this Note sets forth the facts of the case and summarizes the court's reasoning. Part II analyzes the propriety of the court's decision to permit the cross-exammation as an evidentiary inatter. Part III examines the decision on constitutional grounds. The Note concludes that Robeson was wrongly decided from both perspectives, and that evidence of prearrest silence should be inadmissible.

\section{THE OPINION}

\section{A. The Facts of the Case}

The prosecution's evidence suggested that the defendant Robeson shot and killed Stilton Jones during a dispute following a narcotics deal. ${ }^{2}$ The defendant took the stand and demed shooting Jones, selling narcotics, or having a gun. ${ }^{3} \mathrm{He}$ also related an exculpatory version of the event for the first time. He testified that he was leaving his apartment on his way to a restaurant with his girl friend when he heard shots, followed by the sound of a car speeding away. He further testified that he arranged for an ambulance to be called and was still on the scene when the police arrived. On cross-exammation, he admitted that he had moved out of his house in order to hide froin the police, and that he knew a warrant was out for his arrest. After ehciting this testimony, the prosecutor asked defendant the following:

Q. You didn't tell the police what happened. Did you go down to the police and tell them you had nothing to do-

[Defense counsel]: I would object, your Honor.

THE COURT: I think that is a perfectly proper question. I will take the answer.

I. 39 Md. App. 365, 386 A.2d 795 (Ct. Spec. App. I978) (Liss, J.).

2. Id. at $367-68,386 \mathrm{~A} .2 \mathrm{~d}$ at $796-97$.

3. Id. at 368,386 A.2d at 797 . 
Q. [Prosecution] Did you ever tell the police what happened?

A. No, I didn't. I told them what I knew after, you know, afterTHE COURT: You didn't tell them voluntarily, did you?

THE WITNESS: No, I didn't.

THE COURT: That is what the State wants to know.

Q. [Prosecution] You didn't call the police and tell them that you were innocent.

A. No, I didn't. ${ }^{4}$

Defendant was convicted of first degree murder. On appeal, he urged that the trial court erred in permitting the prosecutor to cross-examine him on his failure to voluntarily communicate his exculpatory story to the police prior to his arrest. Robeson did not contest the admissibility of evidence indicating that he was hiding or that he failed to turn himself in to the police.

\section{B. The Court's Opinion}

The Robeson court began by stating that the fifth amendment right to reinain silent arises only when an individual "is confronted by [his] accusers following an arrest or in a custodial interrogation setting." The court stated two reasons why evidence about silence is madmissible when the silence occurs in the postarrest situation. First, the court stated that "silence at the time of arrest lacks significant probative value and carries with it too great a potential for prejudice," citmg United States v. Hale. ${ }^{6}$ Second, the court said that admission of such evidence would "imfringe upon a defendant's Fifth Amendment right to remain silent," citing Doyle v. Ohio. ${ }^{7}$ Considering these reasons for not admitting evidence of silence in the postarrest situation, the court asked whether similar restrictions should be applied to cross-examination on a defendant's silence before his arrest in order to discredit exculpatory testimony that he offered for the first time at the trial on the merits. ${ }^{8}$ The court distinguished four cases from other jurisdictions which the defendant had submitted, ${ }^{9}$ and then turned its attention to United States $v$. Hale. ${ }^{10}$

In Hale, the Supreme Court, acting under its federal supervisory

4. Id. at 370,386 A.2d at 798 .

5. Id. at 368,386 A.2d at 797 (emphasis added).

6. 422 U.S. 171 (1975).

7. 426 U.S. 610 (1976).

8. 39 Md. App. at 369,386 A.2d at 797.

9. People v. Sheperd, 37 Colo. App. 336, 551 P.2d 210 (1976) (prosecution conceded prearrest silence could not be used for impeachment); Webb v. State, 347 So. 2d 1054 (Fla. Dist. Ct. App. 1977) (postarrest silence); Brooks v. State, 347 So. 2d 444 (Fla. Dist. Ct. App. 1977) (prearrest silence used to raise an inference of guilt); Weiss v. State, 341 So. $2 d 528$ (Fla. Dist. Ct. App. 1977) (defendant remained silent prior to arrest on advice of counsel).

10. 422 U.S. 171 (1975). 
power, had determined that the potential for prejudice in evidence indicating a defendant's silence during postarrest custodial interrogation outweighed any probative value of the evidence. The Court found the inherent ambiguity of postarrest silence made such evidence inadmissible to impeach a defendant's trial alibi. ${ }^{11}$ Without discussing the logic of the Hale opinion, the Robeson court stated that the cross-examination about Robeson's failure to disclose his ahbi was "gerinane to his conduct; i.e., his hiding from the pohice," and was necessary to prevent his fabrication of a story. ${ }^{12}$

The court then discussed Doyle v. Ohio. There the Supreme Court held that "the use for impeachment purposes of [defendant's] silence, at the time of arrest and after receiving Miranda warnings, violated the Due Process Clause of the Fourteenth Amendment," since those warnings imphicitly assure that silence will carry no penalty. ${ }^{13}$ The Robeson court cursorily distimguished Doyle as confined to postarrest, custodial circumstanccs, ${ }^{14}$ once again finding it unnecessary to examine the logic of the Supreme Court's policy. The Robeson court closed its discussion of Doyle by noting two observations which Justice Stevens had raised in dissent. First, Justice Stevens thought that the defendants' silence was admissible for purposes of inpeachment as a prior inconsistent statement since it "was graphically inconsistent with their trial testiinony . . .." 15 Second, his view was that defendants waive their fifth ainendinent rights by choosing to take the stand. ${ }^{16}$

11. Id. at 176-77. In Hale, the Supreme Court exercised its supervisory powers over federal courts. Id. at 181. The next term, in Doyle, it reached the constitutional issue.

12. $39 \mathrm{Md}$. App. at 377,386 A.2d at 801 .

13. 426 U.S. at 618-19. Prior to Miranda, the exclusionary rule, see Weeks v. United States, 232 U.S. 383 (1914), had barred the use of illegally seized evidence to prove facts in issue. However, Walder v. United States, 347 U.S. 62 (1954), distinguished Weeks, carving out the exception that where the defendant makes an "affirmative," "perjurious" statement on the stand on a matter collateral to the issue of guilt, the State may use illegally seized evidence to attack his credibility. The Miranda decision, with its language that "the privilege against self-incrimination protects the individual from being compelled to incriminate himself in any manner," 384 U.S. at 476, suggested the overruling of Walder and the inadmissibility of illegally seized evidence even for impeachment. In Harris v. New York, 401 U.S. 222 (1971), however, the Court allowed the use of a statement obtained in violation of Miranda for impeachment purposes. The Harris decision significantly departs from the direction the Court was heading with Miranda and other criminal rights decisions. All that is required under Harris for illegally seized evidence to be used for impeachment is that the evidence be relevant to the defendant's credibility.

The Doyle rule excluding even impeachment use of a defendant's postarrest silence is unuch stricter. It is presumably based on the ambiguous and unreliable nature of silence following $\mathrm{Mi}$ randa warnings. 426 U.S. at 617 . Illegally obtained statements or physical evidence are apparently more reliable.

14. $39 \mathrm{Md}$. App. at $377,386 \mathrm{~A} .2 \mathrm{~d}$ at 801.

15. Id. at 379, 386 A.2d at 802 (citing Doyle, 426 U.S. at $621-22$ (Stevens, J., dissenting)).

16. "[A criminal] defendant who voluntarily foregoes his privilege not to testify and presents exculpatory or mitigating evidence, subjects himself to relevant cross-examination without the right to reclaim Fifth Amendment protection on a selective basis." 39 Md. App. at 379, 386 A.2d 
The Robeson court next considered a case from the District of Columbia that it thought was similar, Ester v. United States. ${ }^{17}$ Ester held that cross-exammation of the defendant about his action im ruming from the police and his failure to offer an exculpatory story at the scene of the crime was "proper simce [it] related to [his] credibility and flight . . .."18 The Robeson court concluded, relying on Ester, that "on the facts of this case the cross-exammation and argument to the jury as to the appellant's pre-trial silence were not impermissible comment on an inference of guilt but rather a permissible imquiry as to the credibility and circumstances of flight." 19

The Robeson court mentioned two rationales for its holding. First, by allowing cross-exammation of prearrest conduct, it sought to avoid allowing the defendant to "fabricate any exculpatory story he chose, to be unveiled for the first time at trial, without the necessity of having to defend his version of the facts against the rigors of cross-examination." ${ }^{20}$ Second, the court thought "[t]he failure of a defendant to conduct himself as would an innocent man may show knowledge of guilt." 21 Thus, cross-examination is permissible "to establish [the defendant's] conduct after the occurrence of the crime."22

\section{THe Evidentiary Issue}

\section{A. Nonconstitutional Evidence Law}

The Robeson court quoted three full paragraphs froin United States $v$. Hale about the inherent ambiguity of postarrest silence. It did not, however, fully discuss the nonconstitutional evidentiary issue that this quoted material raises with respect to prearrest silence. ${ }^{23}$ This is unfortunate since examination of Hale's logic suggests that evidence

at 802 (citing Doyle, 426 U.S. at 629 n.8 (Stevens, J., dissenting) (quoting Fitzpatrick v. Unitcd States, 178 U.S. 304, $315(1900))$ ).

17. 253 A.2d 537 (D.C. 1969).

18. $39 \mathrm{Md}$. App. at 380,386 A.2d at 803 (quoting Ester v. United States, 253 A.2d 537, 538 (D.C. 1969)).

19. $39 \mathrm{Md}$. App. at $380,386 \mathrm{~A} .2 \mathrm{~d}$ at 803 .

20. Id. at 377,386 A.2d at 801 .

21. Id. (quoting Carter v. State, 10 Md. App. 50, 55, 267 A.2d 743, 746 (Ct. Spec. App. 1970)).

22. $39 \mathrm{Md}$. App. at $377,386 \mathrm{~A} .2 \mathrm{~d}$ at 801 .

23. The cross-examination in question was treated as directed at impeachnent of the defendant. However, the court indicated that the cross-exainination might have been used as evidence of guilt, by its statement that the "failure of a defendant to conduct himself as would an innocent man may show knowledge of guilt." 39 Md. App. at 377, 386 A.2d at 801 (quoting Carter v. State, 10 Md. App. 50, 55, 267 A.2d 743, 746 (Ct. Spec. App. 1970)). See notes $79-85$ and accompanying text infra. 
about Robeson's failure to volunteer his exculpatory story should have been ruled inadmissible.

The Robeson court limited its evidentiary discussion to three observations. First, the court stated that refusal to permit cross-examination on prearrest conduct would allow a defendant to fabricate an exculpatory story at trial that he would not have to defend in the face of adverse questioning. ${ }^{24}$ The prevention of fabricated stories is a valid concern, but is irrelevant to the issue in the case. The question was whether the prosecution was entitled to inquire about the defendant's pretrial failure to come forth with his version of events, not whether, once at trial, the defendant's story was for some reason beyond the reach of cross-examination. The court could have barred cross-examination of the defendant's prearrest failure to volunteer his story and still have permitted the most searching questioning both of the story itself and of remaming matters relating to his prearrest conduct. The court's concern that the prosecution needs greater information about possible exculpatory stories to prevent fabrications should be dealt with, not by courts, but by the legislature, which can enact notice-ofalibi discovery statutes ${ }^{25}$ or other appropriate measures.

The real issue in Robeson is not the prosecutor's attempt to gam information for use in constructing his case, but rather his attempt to use the defendant's prearrest silence to discredit his exculpatory story. This concern was amply inet in Robeson by the opportunity for crossexamination about defendant's flight and hiding, without reference to his silence. ${ }^{26}$

The court's second comment on the evidentiary issue was to note

24. 39 Md. App. at 377,386 A.2d at 801 .

25. See Reynolds v. Superior Court, 12 Cal. 3d 384, 528 P.2d 45, 117 Cal. Rptr. 437, modified, 13 Cal. 3d 204b (1974) (Wright, C.J.) (advance sheets only) (Cahfornia Supreme Court held notice-of-alibi statutes should be created by legislature rather than judiciary), noted in The Supreme Court of California 1974-1975, 64 CALIF. L. REv. 286, 509-16 (1976).

Notice-of-alibi statutes require defense disclosure of the names of ahibi witnesses and prosecution disclosure of alibi-rebuttal witnesses. In Williams v. Florida, 399 U.S. 78 (1970), the Court held that the notice-of-alibi statute at bar did not violate the fifth amendinent privilege against self-incrimination, since "[a]t inost [it] only coinpelled petitioner to accelerate the timing of his disclosure." Id. at 85 . The Court stressed the statute's provision for "reciprocal discovery against the State," i.e., the State must disclose its rebuttal witnesses to the defense. Id. at 82 n.11. Maryland has no such statute. This may well reflect a belief by the legislators that to impose such a requirement on the defense would be undesirable.

26. The question of impeachment use of silence prior to arrest would probably arise only where no suspicious prearrest conduct could be ehcited by the prosecution-e.g., the case in which a defendant does not move or hide froin police, but stays at his own apartment until later arrested. Thus, in the general situation, the distinction between prearrest silence and conduct will not exist, and it will be clear that the silence itself should be protected.

In Robeson, the existence of such prearrest conduct might enable the court to find that, although the cross-examination was constitutionally impermissible, it was only harmless error, relying on an unclear statement in Doyle, 426 U.S. at 619-20. In that situation, hopefully the Court 
that the prosecution's questioning was "germane" to Robeson's efforts to elude the police, ${ }^{27}$ and was a permissible inquiry into his credibility. ${ }^{28}$ The court did not inquire into the accompanying issue of the net probative value of such evidence. This is odd in light of the court's preceding quotation from Hale that " in most circumstances silence is so anbiguous that it is of little probative force." "29 This omission is all the more peculiar since Hale utilized an analysis which, although not ineclianically transferable to Robeson, at least illuminates the relevant concerns to be considered in determining probative value.

In Hale, the Supreme Court analyzed the probative value of postarrest silence:

In most circumstances silence is so ambiguous that it is of little probative force. . . . Silence gams more probative weight where it persists in the face of accusation, since it is assumed in such circumstances that the accused would be more likely than not to dispute an untrue assertion. Failure to contest an assertion, however, is considered evidence of acquiescence only if it would have been natural under the circumstances to object to the assertion im question. ${ }^{30}$

With respect to postarrest silence, the Court found that a variety of factors inay cause the defendant to remain silent (e.g., mitimidation by the situation, fear, or unwillingness to incriminate another). In hight of these factors, it would not have been "natural" to offer an explanation. The Court therefore concluded that postarrest silence lacked probative value. $^{31}$

Prearrest silence should be held to lack probative value undcr the saine reasoning. ${ }^{32}$ There are many possible reasons why an individual wlio knows he has been accused of a crime might decide not to contact the police witl his version of the events. Since he is already accused of a crime, he, like a person actually under arrest, inay find any contact with the police intimidating. He might well want to let the investiga-

would repudiate the "harmless error" exception and hold that all prearrest silence should be constitutionally protected.

27. $39 \mathrm{Md}$. App. at 377,386 A.2d at 801.

28. Id. at 380,386 A.2d at 803 .

29. Id. at 375,386 A.2d at 800 (quoting 422 U.S. at 176).

30. 422 U.S. at 176 (citations omitted).

31. Id. at 177 .

32. The impact of the Miranda warnings is not the only reason for holding silence at the time of arrest to be of dubious probative value. "[S]ilence at the time of arrest nay be inherently ambiguous even apart frou the effect of Miranda warnings . . ." Doyle, 426 U.S. at 617 n.8 (citing Hale, 422 U.S. at 177).

Silence has probative value only in the face of an aceusation, where the defendant would be likely to speak up if the accusation were untrue. The greater the period of time between an accusation and the aceused's silence, the unore ambiguous the silence becones. Thus, if silence is ambiguous at the point of arrest and physical detention, silence that oceurs before arrest is even nore ambiguous. 
tion run its course, in the hope that later events would tend to absolve him. He may harbor antipathy towards the police in general,,$^{33}$ or may have been involved in other criminal activity. Any eyewitness might decide not to contact the police for a variety of reasons: perhaps "out of fear or unwillingness to mcriminate another," 34 or out of distaste for getting involved with the law. Thus, since the simple circumstance of known criminal accusation is imsufficient to make it "natural" for an individual to contact the police with an exculpatory story in hand, prearrest silence generally should be held to lack probative value. ${ }^{35}$

Applying Hale's analysis to the prearrest context, then, prearrest silence should be found to be generally as ambiguous as postarrest silence. ${ }^{36}$ Consequently, the cross-examination in Robeson should have been impermissible solely on the basis of evidence law.

\section{B. Constitutionalizing the Evidentiary Argument}

The Supreme Court decided Hale on evidentiary grounds. Since the Court was exercising its supervisory powers over the federal courts, Hale may persuade, but does not control, the state courts. Doyle, imvolving facts similar to Hale's, but coming from a state court, was decided on the constitutional ground that the implicit assurance of the Miranda warnings rendered even impeachment use of postarrest silence a violation of due process. In the review of future state cases which involve no other constitutional issues, the Court could raise the evidentiary basis of Hale to a constitutional level on due process

33. General antipathy towards police or a fear of police intimidation exists especially in minority or lower-class circles. A middle-class person might easily contact the police to clear himself or herself if charged with a crime (frequently, through or on advice of their attorney). A minority or lower-class suspect, lowever, wlo has possibly been mistreated by the police before, could easily believe that any contact with the police is dangerous and any explanation given would not be believed. See, e.g., Wilson, The Police in the Ghetto, in THE POLICE AND THE CoMMUNITY 56-58 (R. Steadman ed. 1972).

34. United States v. Hale, 422 U.S. at 177.

35. Exception may be taken to this general rule where additional information about the circumstances makes it appear more "natural" for an accused eyewitness to contact police before arrest, as, for example, where the victim and the accused were relatives. Justice Stevens' dissent in Doyle provides another example. There the defendant did talk to police, but said nothing at that time about what later was claimed to be a frame-up. Justice Stevens concluded that "a failure to advise the police of a 'frame' at a time when it inost surely would be mentioned if [defendant's] trial testimony were true" is a prior inconsistent statement. 426 U.S. at 628 . To note such inconsistency is equivalent to stating that it would be "natural under the circuinstances" for the defendant to speak to police. Neither of these examples are relevant to the Robeson case.

36. Some courts have lield that comment upon a criminal defendant's pretrial silence as to a defense asserted at trial is permissible only in exceptional cases of total inconsistency between the asserted defense and the pretrial silence, and if any rational explanation exists for that silence, it may not be used to impeach him. See, e.g., United States v. Harp, 513 F.2d 786, 789 (5th Cir.), rehearing denied, 516 F.2d 900 (5th Cir.), vacated and remanded, 423 U.S. 919 (1975), rev'd on remand, 536 F.2d 601 (5th Cir. 1976). Robeson does not present such total inconsistency, since several rational explanations exist for his silence. 
grounds. The Court could hold that admission of evidence of simple prearrest silence for any purpose would be fundamentally unfair because such evidence is too ambiguous to show anything.

The Court has often constitutionalized evidence law through such a due process analysis. ${ }^{37}$ A conviction based on no evidence has been held violative of due process. ${ }^{38}$ So have convictions based on certain statutorily created irrebuttable presumptions, "if there is no rational connection between the fact proved and the ultimate fact presumed." 39 Moreover, if a state evidence rule excludes evidence of fundamental importance, application of the rule has been leeld to violate due process. ${ }^{40}$

Hale's treatment of postarrest silence indicates that the Court found it inherently anbiguous and without probative value. Prearrest silence is similarly anbiguous. ${ }^{41}$ It thus would be consistent with due process principles to find the use of the evidence in Robeson too ambiguous to be permissible under due process. ${ }^{42}$

\section{III}

\section{The Constitutional Issues}

The Robeson court confined its discussion of the constitutional issues in the case to an analysis of the constitutional authority of Doyle $v$. Ohio. The Doyle case barred the use of postarrest silence arismg in a custodial setting to impeach a defendant's trial testimony. In the Robeson court's view, Doyle did not extend to prearrest, noncustodial silence. ${ }^{43}$ The Doyle opimion did not hold, however, that the fifth

37. "[T]he Fifth and Fourteenth Amendments [command] that federal and state trials must be conducted in accordance with due process of law. It is by this standard that I would test federal and state rules of evidence." Dutton v. Evans, 400 U.S. 74, 96-97 (1970) (Harlan, J., concurring) (holding state coconspirator exception to the hearsay rule did not violate due process).

38. See Shuttlesworth v. Birmingham, 382 U.S. 87 (1965); Barr v. Columbia, 378 U.S. 146 (1964); Gamer v. Louisiana, 368 U.S. 157 (1961); Thompson v. Louisville, 362 U.S. 199 (1960).

39. Tot v. United States, 319 U.S. 463, 467-68 (1943) (due process violated by statutory presuinption that a firearm was acquired in interstate commerce when it is possessed by a defendant convicted of a previous crime). See also Leary v. United States, 395 U.S. 6 (1969) (provision deeming possession of marijuana to be sufficient evidence to show defendant knew of illegal importation is unconstitutional); Allen v. County Court, 568 F.2d 998 (2d Cir. 1977) (statutory presumption that occupants of a vehicle possess a weapon found therein is unconstitutional on its face).

40. Chambers v. Mississippi, 410 U.S. 284 (1972) (apphication of state rules of evidence that precluded defendant from impeaching adverse testimony of his own witness violates due process).

41. See notes 30-36 and accompanying text supra.

42. Several other cominentators have suggested this possible approaeh by the Court. Notc, Evidence: Use in the Federal Courts of Accused's Silence After Miranda Warnings to Impeach Hls Trial Testimony, 11 LAND \& WATER L. REv. 289, 297 (1976); Comment, Evidence-Doyle v. Ohio: Use of a Defendant's Silence for Impeachment at Trial, 8 LoY. CHI. L.J. 438, 457 (1977).

43. 39 Md. App. at 377,386 A.2d at 801 . 
amendment applies exclusively to postarrest, custodial situations, and the decision contams no language requiring such a limitation. Rather, the Doyle Court found that "the use for impeachment purposes of defendant's silence, at the time of arrest and after receiving Miranda warnings, violated the Due Process Clause of the Fourteenth Amendment,"44 on the ground that Miranda warnings implicitly assure that silence will carry no penalty. By focusing on fourteenth amendment due process rights triggered by the implicit assurances of Miranda warnings, the Doyle opinion raised policy concerns that were not considered in Robeson. The Robeson court did permit Robeson to be penalized for his prearrest silence by allowing the silence to be introduced in cross-examination for impeachment purposes. ${ }^{45}$ The court did not, however, describe why such a penalty was reasonable in the prearrest situation when it was not permitted for postarrest silence. The Robeson court thus shirked its responsibility by not examining the policy reasons underlying Doyle and determining whether they were apphicable to the Robeson situation.

This section will analyze the constitutional issues raised by the cross-examination in Robeson. First, it will examine the Doyle decision and consider whether the assurance of no penalty for silence which is implicit in Miranda warnings should extend to prearrest silence. In considering the extension of Doyle, this section will also explore whether the Doyle rationale could require protection of implicit assurances other than those rooted in Miranda warnings. The second part of this section will argue that the cross-examination in Robeson was unconstitutional because the defendant should have been found to have a fifth amendinent right to remain silent under the circumstances. Permitting cross-examination-either for the purpose of impeaching testimony or demonstrating guilt-had the effect of impermissibly burdening the exercise of this right.

\section{A. The Logic of Extending Doyle}

\section{Extending the Implicit Assurances of Miranda Warnings to Prearrest Silence}

The Robeson court correctly observed that Doyle concerned a defendant's silence " 'after receiving Miranda warnings at the time of. . .

44. 426 U.S. at 619 . The Robeson court thus erred in reading Doyle as a fifth amendment holding. See 39 Md. App. at 368-69, 386 A.2d at 797.

45. Indeed, the penalty in Robeson carried weight beyond mere impeachment of testimony. The court said that, particularly since the defendant admitted he was an eyewitness to the crime, his failure to contact the police was possibly a "failure . . . to conduct himself as would an innocent man," which "may show knowledge of guilt." 39 Md. App. at 377, 386 A.2d at 801 (quoting Carter v. State, 10 Md. App. at 55, 267 A.2d at 746 (emphasis added)). 
arrest." "46 It reasoned that there were no Miranda warnings in the prearrest situation in Robeson, and hence no imphicit assurance, as in Doyle, that the defendant's silence would carry no penalty. ${ }^{47}$

This chain of reasoning overlooks important points. In hight of Doyle, postarrest silence, even absent Miranda warnings, should not be used for impeachment purposes. A contrary holding would induce the police to dispense with Miranda warnings, especially where they thought a particular arrestee would not talk to thein, but would later testify. In such a case, the state would gain froin failure to give $\mathrm{Mi}$ randa warnings. The police would forego nothing, since the arrestee would not have talked in any event, while the absence of a Miranda warning would provide the state with a weapon on cross-examination. This is clearly an impermissible result. ${ }^{48}$

If Doyle's "implicit assurance" logic does apply when Miranda warnings are not given at the time of arrest, it can also apply when the warnings are not given before arrest. The Miranda warnings and an arrestee's right to remain silent are widely known. ${ }^{49}$ In many cases, the silence of an unwarned arrestee will be based on his personal knowledge of his Miranda rights. Tlus, the "implicit assurance" that his silence will not be used agamst him is still present. ${ }^{50}$

In light of this widespread awareness of the Miranda warnings,

46. $39 \mathrm{Md}$. App. at 378,386 A.2d at 801 (quoting Doyle v. Ohio, 426 U.S. at 611 ).

47. While Doyle was decided on grounds of fundainental fairness and the fourteenth annendment, the Court could have held that use of the defendant's silence, which may have been in the exercise of his fifth ainendment right, to impeach him would impermissibly burden that right. See notes 61-78 and accompanying text infra. But cf. Scholl, Self-Incrimination, 16 AMER. CRIM. L. REV. 37 (1978) (court refrained froun deciding cases on fifth amendinent grounds); Coinment, Evidence-Doyle v. Ohio: Use of Defendant's Silence for Impeachment at Trial, 8 LoY. CHI. L.J. 438,455 (1977) (fifth amendment right requires a "nonambiguous assertion" of the privilege).

48. The constitutional privilege agamst self-incrimmation does not spring into being upon recitation of the litany of Miranda warnings. Rather, when an mdividual is confronted with a "compelling atmosphere," Miranda v. Arizona, 384 U.S. 436, 465 (1966), law enforcement officials are required to safeguard the privilege by informing the imdividual of that right. Id. at 469 . Since the focus is on the atmosphere that gives rise to the right, postarrest silence, accoinpanied or not by Miranda warnings at arrest, cannot be used for impeachment. See, e.g., Webb v. State, 347 So. 2d 1054, 1056 (Fla. Dist. Ct. App. 1977). This argument, based as it is on the fifth ainendment privilege, and not just on fundamental fairness, further demonstrates that Doyle could have been decided on fifth amendment grounds alone.

49. Even before Miranda there was general public awareness of fifth amendinent rights. Courts had taken notice of it previously: "While [defendant] is in custody, it is common knowledge that he has a right to say nothing." McCarthy v. United States, 25 F.2d 298, 299 (6th Cir. 1928).

50. Police must of course give Miranda warnings, no matter how probable it is that the arrestee knows his rights. The warnings are required as a procedural safeguard im all cases, and there is no inquiry into whether a defendant's silence is in actuality based on an exercise of his right. Miranda v. Arizona, 384 U.S. at 468-69. "[T]he unfairness oceurs when the prosecution . . . is allowed to undertake impeachment on the basis of what may be the exercise of a right." Doyle v. Ohio, 426 U.S. at 620 n.10 (emphasis added). 
Miranda protection logically should apply in the prearrest context. The warnings are required whenever "an individual is taken into custody or otherwise deprived of his freedom by the authorities in any significant way and is subjected to questioning."51 Thus, as soon as he comes into contact with the police, an individual with a warrant out for his arrest is within the Miranda uunbrella, and must be given the warnings. But the suspect wlio knows that a warrant is out for his arrest realizes that should he go to the police with his exculpatory story, they will at once place him under arrest, and this will entitle him to Miranda protection. By choosing silence as his most prudent option, such an unwarned but knowledgeable suspect may be relying on the "imphicit assurances" of Miranda just as inuch as the unwarned arrestee. Fear of self-incrimination legitimately could motivate this choice, smce should the suspect phone or write the police to convey his story, such communications would be voluntary statements that could be used as evidence against him. 52

Despite this logic, it is doubtful that the present Suprene Court would extend Doyle on this basis to persons not yet arrested. The Court continually lias been restricting Miranda by limiting it to its facts, whicl involved custodial interrogations, ${ }^{53}$ rather than applying its rationale to all those situations where "inherently compelling pressures . . . work to undermine the individual's will to resist and to com-

51. Miranda v. Arizona, 384 U.S. at 478.

52. The risks of self-incrimination that the suspect faces by contacting the police are substantial. To avoid inpeachment by his prearrest silence should he take the stand at trial, he inust make statements which, if inculpatory, may be used as part of the state's case-im-chief, and, if exculpatory but inconsistent with later statements, may be used to impeach him on cross-examination.

It might be argued that the prearrestee, though, has other options. He could, for instance, consult an attorney, explain his situation, ask the attorney about what he should or should not say if apprehended, and follow that advice. Or he could surrender silently or with a phrase like, "I have an alibi you'll find out in court." But see State v. White, 97 Idaho 708, 551 P.2d 1344 (1976) for a classic exainple of just how little rope an uncounseled suspect needs to hang himself:

Q. Did you suggest anything to the cops at that tine?

A. I told them, look . . . I don't care what you are going to charge me with, I said, I have an ahibi. I said, I was with somebody all night. They said who, and I said Karen. They said, "Well, that's who we are arresting you for kidnapping."

Id. at $713 \mathrm{n} .7,551 \mathrm{P} .2 \mathrm{~d}$ at $1349 \mathrm{n} .7$.

53. See, e.g., Oregon v. Mathiason, 429 U.S. at 496-99 (Marshall, J., dissenting); Beckwith v. United States, 425 U.S. 341, 349 (1976) (Brennan, J., dissenting).

The Supreme Court has been narrowing the scope of the "custodial interrogation" that will trigger Miranda, by emphasizing actual restriction of hberty. Where a defendant had merely been a suspect and his freedoin had not been restricted, the Court held there to be no custodial interrogation. Compare Orozco v. Texas, 394 U.S. 324 (1969) (Miranda applicable to at-home questioning of suspect under arrest and "deprived of his freedoun of action") and Mathis v. United States, 391 U.S. 1 (1968) (Miranda apphicable to in-prison questioning of suspect incarcerated there on a separate offense) with Oregon v. Mathiason, 429 U.S. 492 (1977) (Miranda not applicable to station house questioning of suspect parolee who had gone there after a police officer "suggested" he do so). 
pel him to speak where he would not otherwise do so freely."54 The Court repeatedly has referred to Miranda warnings as a "prophylactic rule"55 designed to safeguard the privilege against self-incrimination, rather than a rule mandated by the fifth ainendinent itself. As a result, the Court does not autornatically invalidate impeachment use of questionable evidence in cases where the Miranda warnings are not given. Instead, it looks at Miranda's underlying policies-deterrence of police misconduct and rehability of statements-to determine whether to admit the evidence. ${ }^{56}$ In Beckwith v. United States, ${ }^{57}$ the Court declined to extend Miranda to compelling situations of a noncustodial nature. It rejected defendant's argument that "he was placed in the functional, and, therefore, legal equivalent of the Miranda situation." 58 However, it left open the possibility of extending Miranda to prearrest situations if they were custodial and if "special circuinstances" were present. 59

\section{Extending the Implicit Assurances of Doyle on Due Process Grounds}

Even if Doyle is held not to extend to the prearrest situation on the basis of the Miranda warnings, there is a more general sense in which Doyle's emphasis on imphicit assurance of no penalty may be apphed to prearrest silence. The Court probably thought it was taking a narrow course in deciding Doyle on fourteenth rather than fifth ainendment grounds, but the decision has potentially greater scope for expansion.

Doyle could extend to the prearrest silence situation, in that it would violate due process to penalize a citizen for remaining silent in a situation in which there was no legal duty to talk. In general, our society is individualistically oriented. Our legal system reflects this attitude by assuring individuals that voluntary action, even though socially beneficial, will not be legally compelled. For example, there is no legal duty to aid a person in distress. ${ }^{60}$ If such general social attitudes are sufficiently clear, then Doyle could imply that it is fundamentally unfair first to assure a citizen that personal initiative to advance collective

54. Miranda v. Arizona, 384 U.S. at 467.

55. See, e.g., North Carolina v. Butler, 99 S. Ct. 1755, 1758 (1979); Michigan v. Tucker, 417 U.S. 433,439 (1974).

56. 417 U.S. at 439 .

57. 425 U.S. 341 (1976) (Miranda warnings not required when Internal Revenue Service agents questioned a defendant uot in formal custody).

58. Id. at 346.

59. Id. at $347-48$.

60. Handiboe v. McCarthy, 114 Ga. App. 541, 151 S.E.2d 905 (1966) (no duty to rescue child licensee drowning in pool); Osterlind v. Hill, 263 Mass. 73, 160 N.E. 301 (1928) (defendant, who rented canoe to obviously intoxicated person who upset it, had no duty to rescue him). See W. Prosser, HaNDBOOK OF THE LAW OF TORTS 340 (4th ed. 1971). 
ends is not required (e.g., reporting an eyewitnessed crime) and then to penalize a person for relying on those assurances.

\section{B. The Problem of Burdening the Fifth Amendment}

The Supreme Court consistently has held that it is constitutionally impermissible to fetter a defendant's free choice of the exercise of his fifth amendment privilege against self-incrimination by attaching high costs to the exercise of that right. ${ }^{61}$ In Slochower v. Board of Education, ${ }^{62}$ for exainple, the Court held that a public school teacher could not be discharged merely because he had invoked the privilege against self-incrimination before a congressional committee.

This section will consider whether prearrest silence, irrespective of knowledge of a warrant, is protected by the fifth amendment. If prearrest silence is so protected, it would be improper later to use evidence of that silence against the defendant. Forcing a defendant to choose between adverse use of his prearrest silence and self-incrimination would create just the sort of "impermissible condition imposed upon the fifth amendment privilege that the Supreme Court has condemned." 93

\section{Prearrest Silence: A Fifth Amendment Right?}

For the fifth annendment privilege ${ }^{64}$ to exist, an individual's statements must be both compelled ${ }^{65}$ and testimomial, ${ }^{66}$ and must expose the

61. For example, threatening job-related retaliation for invoking the privilege is coercive and has been held to unconstitutionally burden the privilege. Lefkowitz v. Cunningham, 431 U.S. 801 (1977) (removal froin office and disqualification for five years in case of political party officer); Lefkowitz v. Turley, 414 U.S. 70 (1973) (disqualification froin public contracts in case of architects); Spevack v. Klem, 385 U.S. 511 (1967) (disbarment).

It slould be noted in passing that Robeson can be viewed as laving exercised his fifth amendment privilege even though he did not orally claim it. It seems unrealistic and pointless in the present case to require that the privilege be invokcd by word-i.e, an announcement by the fugitive to authorities that he or slie intends to report no alibi on the basis of a fifth amendment right-rather than by the act of refraining from communication with police. Consequently, Robeson's failure to specifically claim his constitutional right should be irrelevant.

62. 350 U.S. 551 (1956).

63. Garrity v. New Jersey, 385 U.S. 493, 501 (1967) (Harlan, J., dissenting).

64. "No person ... . shall be compelled in any crimmal case to be a witness against himself . . . U.S. Const. amend. V.

65. "[T]he Fiftl Amendment proscribes only self-imcrimination obtained by a 'genuine compulsion of testimony.' . . . Absent some officially coerced self-accusation, the Fifth Amendment privilege is not violated . . . United States v. Washington, 431 U.S. 181, 187 (1977) (citation omitted) (no compulsion where a grand jury witness was given warnings and voluntarily answered questions); Fisher v. United States, 425 U.S. 391, 421 (1976).

66. "[T]lie privilege [against self-mcrinination] protects an accused only from being coinpelled to testify agamst himself or otherwise provide the State with evidence of a testimonial or communicative nature." Schınerber v. California, 384 U.S. 757, 761 (1966) (emphasis added) (witlidrawal of blood for alcoliol test was noncommunicative and did not violate the fifth annend- 
defendant to "substantial risks of self-incrimination."67 Compulsion was present in Robeson; the decision essentially promulgates a rule that an eyewitness to a crime unust inform the police of what he witnessed or risk impeachment should he later be charged with the crime and take the stand in his own defense. Even though the silence in issue is prior to arrest and the defendant is not in a custodial situation, compulsion is present because of the threat of a later sanction.

Robeson's reporting requirenient is also testimonial. It requires the suspect to tell his exculpatory version of events to the police, or risk impeachment. Although the Court has lield that regulatory, noncriminal reporting systems requirmg disclosure of name and address do not elicit testimonial information, ${ }^{68}$ the information requircd by Robeson is nore extensive than the "essentially neutral act" of name and address disclosure. ${ }^{69}$

The third element that must be considered in establishing the existence of a valid fifth amendment privilege is the degree to which the defendant risks incrimination by his statements. The Court has held that the government may require the filing of reports such as income

ment); California v. Byers, 402 U.S. 424, 432 (1971) (statutory requirement that participant in an automobile accident disclose his name and address held not testimonial).

67. California v. Byers, 402 U.S. at 429; Marchetti v. United States, 390 U.S. 39, 48 (1967).

The Supreme Court decisions defining the application of the privilege against self-incrimination do not ring with clarity. The basic test seems to be a threshhold determination of whether "the claimant is confronted by substantial and 'real,' and not merely trifling or imaginary, hazards of imcrimination." Marchetti v. United States, 390 U.S. at 53. If there is a substantial risk of incrimination, then the evidence must be compelled and testimonial to raise the privilege.

The Court confused the incrimination test, however, by manipulating the definition of the target group to which the disclosure requirement is directed. For example, in California v. Byers the Court states that the hit-and-run disclosure statute was "directed at . . . all persons who drive automobiles in Cahfornia," 402 U.S. at 430, rather than at the highly selective group of "all persons who drive automobiles in California who are involved in accidents causing property damage." Id. at 461 (Black, J., dissenting) (emphasis in original). Use of such a manipulative approach in defining the target group can remove fifth amendment protection for any group.

The Court's fornulation of the testimonial prong is also confusing. This requireinent had been developed to distinguish between coinpelled communications and "compulsion which inakes a suspect or accused the source of "real or physical evidence," " such as "a suspect's normal voice characteristics, handwriting, blood, fingerprints, or body." Schmerber v. California, 384 U.S. at 764. In Byers, the Court declared that the requirement to disclose name and address, though a communication, is not testimonial. To support this assertion, the Court stated that the disclosure "is no more incriminating" than tax returns which prior cases had found acceptable. 402 U.S. at 434. By essentially holding that the disclosure requirement is not testimonial because it is not very incriminating, this analysis confuses elements of the fifth amendment test that the Court sets forth as separate. $I d$. at $427-34$.

These inconsistencies suggest that the constitutional definitions of "counpelled" and "testimonial" depend on what the Court feels is proper in each situation, and that unprincipled decisional balancing is taking place. A preferable approach would be to clarify the factors that the Court weighs in deterunining the application of the fifth amendment privilege. See, e.g., The Supreme Court, 1970 Term, 85 HaRv. L. Rev. 40, 269 (1971).

68. California v. Byers, 402 U.S. at 431-32. See note 67 supra.

69. 402 U.S. at 432. 
tax returns, ${ }^{70}$ automobile accident reports, ${ }^{71}$ and securities informational statements. ${ }^{72}$ However, the burden of reporting information in these cases is "directed at the public at large" in "an essentially noncriminal and regulatory area of inquiry." 73 When the burden is instead directed at a "highly selective group "inherently suspect of criminal activities' . . . m 'an area permeated with criminal statutes," "74 the statutory system creates a substantial risk of incrimination, which the court las lield constitutionally impermissible. ${ }^{75}$

Under this analysis, the Robeson reporting requirenent may well pose "substantial risks of self-incrimination." The requirement is not directed at eyewitnesses to crime in general, but only at the "highly selective group" of eyewitnesses for whom an arrest warrant has been issued. ${ }^{76}$ Furthermore, the stated purpose of the requirement, to validate suspicions about criminal suspects, is readily open to abuse. When "zealous officers" enterprise of ferreting out crime," 78 a Robeson reporting requirement may be used by police as a means of gathering evidence against suspects rather than as a method of ensuring that arrest warrants are well founded. Since the information sought raises a substantial risk of incrimination, and is both compelled and testimomial, Robeson should have been found to have a fifth amendment right to remain silent by refusing to volunteer his exculpatory story prior to his arrest.

70. United States v. Sullivan, 274 U.S. 259 (1927), cited with approval in California v. Byers, 402 U.S. at $428-29$.

71. California v. Byers, 402 U.S. 424.

72. Id. at 428 .

73. Id. at 430 (quoting Albertson v. SACB, 382 U.S. 70,79 (1965)).

74. 402 U.S. at 430 (quoting Marchetti v. United States, 390 U.S. 39 (1968); Albertson v. SACB, 382 U.S. at 79).

75. Albertson v. SACB, 382 U.S. at 79 (order requiring Communist Party members to register with the Subversive Activities Control Board violated the fifth amendment privilege against self-incrinination). See also Haynes v. United States, 390 U.S. 85 (1968) (violates privilege against self-incrimination to require defendant to register a firearm when such possession is per se unlawful); Grosso v. United States, 390 U.S. 62 (1968) (statute requiring filing of a special tax return for wagering income violates privilege); Marchetti v. United States, 390 U.S. 39 (1968) (statute requiring registration and payment of taxes for wagering violates privilege against selfincrimination).

76. If all eyewitnesses to a crime were required to give their names and addresses to the police, and violation of this rule was a inisdemeanor (rather than a basis for impeachment at trial), then this would probably not violate the fifth amendment, according to Byers, since this variation on the Robeson facts would neither be testimonial nor directed at a group "inherently suspect." If the only persons charged with this violation, however, were eyewitnesses who also had been cliarged with the crime, then perhaps this would violate the privilege.

77. Johnson v. United States, 333 U.S. 10, 13 (1948).

78. Id. at 14. 


\section{Cross-examination: An Impermissible Burden?}

a. Impeachment Use

Cross-examination adducing evidence about prearrest silence should have been found to have exacted "a high cost" from Robeson, one which fettered his exercise of his fifth amendment rights. Indeed, the very motivation of the prosecution to display evidence of the silence sprang from the prejudicial association inherent in the evidence. This prejudicial effect can be powerful even when the evidence is introduced for the limited purpose of impeaching a defendant's contrary exculpatory story, since this aims a destructive blow at what frequently will be the central pillar of the defense. Although the precise prejudicial effect will vary in different cases, it would be sensible as a general inatter to consider such evidence a "high cost" to the defendant, thereby prohibiting its introduction.

Such a uniform exclusionary rule would have some overly broad effect since it would bar both evidence that could be highly damaging to the defense and evidence that, if properly used solely for impeachment purposes, could have only shight impact on the resolution of a case. However, since the utility of evidence to the prosecution is defined by the extent of its damaging impact upon a defendant, exclusion of evidence of silence which is useful only for impeachinent purposes should engender only slight prosecutorial interest. Furthermore, such a uniform exclusionary policy would have the advantage of precluding courtroom controversies about the "costliness" of particular cross-examinations. These controversies should be resolved in favor of the defendant anyway since the prosecutor would not seek to introduce evidence of silence if he did not believe it would actually have an impact beyond its nominal use for impeachinent purposes.

\section{b. Evidence of Guilt}

Even assuming that Robeson's prearrest silence could permissibly be used for impeachment, ${ }^{79}$ there is a strong danger that the jury will take it as direct evidence of guilt. ${ }^{80}$ The Supreme Court has held that

79. Evidence obtained in violation of a constitutional right has sometimes been admitted for impeachment use, if the evidence has been found to be reliable. See, e.g., Harris v. New York, 401 U.S. 222 (1971). See note 13 supra.

80. The danger that a jury will not be able to make the fine distinction between evidence used for impeachment of credibility and evidence of guilt las often been noted: "Such distinctions [evidence of guilt or for impeachment] may be meaningful to lawyers and judges, but it is likely to inean little to juries, no matter how well instructed by courts." Wall St. J., Mar. 2, 1971, at 16, col. 2, quoted in Coininent, Evidence-Doyle v. Ohio: Use of Defendant's Silence for Impeachment at Trial, 8 LoY. CHI. L.J. 438, 454 n.81 (1977).

To instruct a jury that they are not to consider expressions of complicity in the charged crime as evidence that the speaker in fact committed the charged crime, but only for the purpose of demonstrating that le was probably lying when he denied cominitting the 
the prosecution cannot, as evidence of guilt, comment on a defendant's silence in the exercise of his privilege against self-incrimination. ${ }^{81}$

The Robeson court itself seems to have regarded Robeson's silence as an indication not only of the weakness of his exculpatory story but also of the very fact of his guilt. The court intertwined Robeson's conduct with his silence and permitted questions about his silence as "germane to his conduct." 82 The prosecutor's questioning implied that if the defendant was innocent he would have contacted the police. Therefore, his failure to talk to the police was inconsistent with his innocence, not simply with his testimony. If, however, Robeson's refusal to talk to the police was protected by his fifth amendment right, ${ }^{83}$ the prosecutor impermissibly inferred that the defendant's exercise of this right was evidence of guilt. ${ }^{84}$ The privilege against self-incrimination would indeed be "reduced to a hollow mockery"85 if exercising it results in self-incrimination just as much as not exercising it.

\section{CONCLUSION}

The Robeson case was inadequately analyzed and wrongly decided. The Supreine Court opinions in Hale and Doyle firmly establish the evidentiary and constitutional bases for excluding evidence of postarrest silence for impeachment use. Hale's evidentiary policy should exclude similarly aunbiguous evidence when it arises, as in Robeson, in a prearrest setting. Doyle's constitutional "implicit assurances" hikewise ought to protect the defendant who, like Robeson, fails to talk to the police knowing there was a warrant out for his arrest, although the trend of current Supreme Court decisions is away from such an extension of Doyle. These assurances inay apply as well to inore general situations where defendants, not presently charged with a crime, fail to volunteer their stories. Finally, Robeson was wrongly decided if, as argued here, there exists a fifth amendinent right to prearrest silence together with provision for its free exercise.

charged crime, would be to require, in the words of Learned Haud, "a mental gymnastic which is beyond, not only [the jury's] power, but anybody."

People v. Disbrow, 16 Cal. 3d 101, 112, 545 P.2d 272, 279, 127 Cal. Rptr. 360, 367 (1976) (citation omitted).

81. Griffin v. Cahfornia, 380 U.S. 609 (1965) (impermissible for prosecutor to comment on defendant's failure to testify in his own defense as showing evidence of guilt).

82. $39 \mathrm{Md}$. App. at $377,386 \mathrm{~A} .2 \mathrm{~d}$ at 801 .

83. See notes $64-78$ and accompanying text supra.

84. "One of the basic functions [of the fifth amendment] is to protect innocent men. . . . [T] he privilege serves to protect the innocent who otherwise might be ensnared by ambiguous circumstances." Grunewald v. United States, 353 U.S. 391, 421 (1957). "While sometimes a 'shelter to the guilty,' the Fifth Amendment is often 'a protection to the innocent.' " Murphy v. Waterfront Comm'n, 378 U.S. 52, 55 (1964) (quoting Quinn v. United States, 349 U.S. 155, 162 (1955)).

85. Slochower v. Board of Educ., 350 U.S. 551,557 (1956). 
The Robeson court's infringement of these elements of constitutional and evidentiary law is particularly unappealing due to the small cost accoinpanying their observance. The prosecution's ability to crossexainine a defendant about whether he had been in hiding or had turned himself in would not be undermined; only cross-examination about prearrest silence would be improper. ${ }^{86}$ Voluntary statements by eyewitnesses who were later charged with a crime would not be excluded, since these statements would not be compelled. ${ }^{87}$ If the legislature should conclude there is a need for greater prosecutorial inforination, it can enact notice-of-ahbi statutes. Particularly since these costs are so small, prearrest silence should be accorded the protection mandated by the Constitution and evidence law.

Terry Gross*

86. In Robeson, for example, the prosecution had already elicited from the defendant the fact that he knew a warrant was out for his arrest, that he had left his own house and moved to his girlfriend's, and that he was hiding from the police, before asking the objectionable questions about the defendant's failure to give an exculpatory statement to the police. $39 \mathrm{Md}$. App. at 377, 386 A.2d at 797.

87. See, e.g., Garner v. United States, 424 U.S. 648 (1976) (the possibility of prosecution for failure to file an income tax return is not compulsion for making meriminating statements on the return, since the defense of the privilege agamst self-incrimination is available for not answering).

* B.A. 1968, Brown University; third-year student, Boalt Hall School of Law. 